\title{
Mobility, Accessibility and Quality of Later Life
}

\author{
Charles Musselwhite and Hebba Haddad
}

\begin{abstract}
Older people are more active and fit than previous generations. Hence, they are more mobile than ever. However, they continue to suffer a reduction in quality of life when giving-up driving. This paper reports research carried out to identify the role of mobility and accessibility in older people's self-reported quality of life, through an in-depth examination of older people's travel needs. A wholly qualitative approach, utilising a variety of data collection methods including focus groups, interview and diary completion, was employed with 57 people aged over 65 in the UK, of which 26 were drivers and 31 had recently given-up driving. The findings emphasise the importance of mobility for accessing services and shops. However, the reasons why older people travel and the importance of mobility go beyond accessibility to include the desire for independence, control, maintaining status, inclusion, "normalness" and travel for its own sake. These are all related to an individual's perception of quality of life. When older people give-up driving their self-reported quality of life is reduced and this seems very much related to a reduction in affective and aesthetic qualities of mobility that a car affords that walking and using public transport lacks. It is suggested that policy and practice needs to consider such motives for travel.
\end{abstract}

\section{Introduction}

Mobility and accessibility are key to maintaining good health and well-being amongst older people and are linked to objective and subjective impressions of quality of life (Fonda, et al., 2001; Ling \& Mannion,1995; Metz, 2000; Webster et al., 2002).Mobility, defined as the amount of travel undertake, is different to accessibility, defined as the amount of opportunities reached, but both are often interrelated and studied together, although they do not always have to be (see Adams, 1999). Traditionally research suggests that reduced mobility will lead to reduced accessibility and this will negatively opportunities to partake in society and reduced social interactions, all resulting in a reduced quality of life (for example, Ling \& Mannion, 1995; Webster et al., 2002). Research into an ever growing hypermobile society, where people are travelling more than ever before by private car, suggests that an increase in mobility is not proportionally linked with an increase in accessibility and improved quality of life (Adams, 1999). Indeed some studies suggest increased mobility could reduce quality of life, for example, the increase in dominance of the motor vehicle

This is a final pre-print version of: Musselwhite, C. and Haddad, H. (2010). Mobility, accessibility and quality of later life. Quality in Ageing and Older Adults. 11(1), 25-37. ISSN: 1471-7794 (Print) 2042-8766 (Online) 
reduces social interactions at a local level (Hart, 2008). In addition, increased mobility by the car can negatively reduce mobility by other forms of transport, for example, walking and cycling are seen as dangerous in light of an increasing number of cars (Engwicht, 1999).

Increased longevity and better health and social care enable older people to remain mobile for much longer than ever before. However, they are more likely than previous generations to need the use of a car to fulfil mobility needs. In an increasing hypermobile society where there is a growing reliance on the car, shops and services are found situated further afield from residential areas, resulting in a need for more mobility to achieve the same level of accessibility (Adams, 2000). In addition, the younger cohort of older people (those aged 60-65) are more likely than those older to have driven all their adult life, creating a habitual pattern of behaviour difficult to break (Musselwhite \& Haddad, 2007). Statistics bear this out; in 1989 26\% UK adults aged over 70 held a driving licence and by 2006 47\% held licences (DfT, 2006) (with a particular increase in the number of female drivers. DfT, 2001; Oxley, 1991). People are driving until later in life and are driving more miles than before (Tomassini, 2004). Hence, in order to reach opportunities older people have to be more mobile and have to use a car. However many older people have to (or may wish to) give-up driving, and this group is the most likely group to suffer mobility deprivation (DfT, 2001) and have most difficulties in accessing vital services (ONS, 2004).

This paper will examine the travel needs of older people in light of mobility issues associated with giving-up the car and address how both mobility and accessibility impact on older people's quality of life as defined by themselves. Hence, the paper will attempt to see if mobility and accessibility are always linked when defining quality of life for older people.

\section{Methodology}

\section{Research Framework}

As travel is largely a social behaviour involving relationships and interactions between people (O'Connell, 2002) a post-structuralist methodology, for which a modified grounded theory approach, where participants are co-researchers throughout the research process, was adopted (Strauss and Corbin, 1998; Glaser, 2001). This suited the nature of generating and developing knowledge and meaning from a wide variety of opinions and attitudes, without doing an injustice to their diversity and depth, using various methodological tools.

\section{Participants}

The study involved 57 individuals ( 36 men and 21 women) aged from 65 to 92 years of age, with a mean age of 72, who lived in the South West of England. They were recruited through the help of Help the Aged and Age Concern charity groups from lists of individuals who wish to be

This is a final pre-print version of: Musselwhite, C. and Haddad, H. (2010). Mobility, accessibility and quality of later life. Quality in Ageing and Older Adults. 11(1), 25-37. ISSN: 1471-7794 (Print) 2042-8766 (Online) 
involved in local consultations. A total of 100 participants were selected to represent a variety of different criteria known to be linked to mobility and accessibility, including location (rural, urban and suburban areas), driving status, age (spread across the age range), physical health, gender and had a range of socioeconomic status. The 100 participants were telephoned and a total of 57 agreed to take part in the research and they were not different in background compared to the originally selected 100 participants. Twenty six were current drivers, driving on average 109 miles a week, and 31 participants had given up driving within the previous 6 to 18 months. Immediately prior to giving up they drove on average 91 miles a week.

\section{Procedure}

A variety of qualitative techniques were employed to collect different aspects of mobility need. The study consisted of two waves of focus groups with participants being split into groups of nine or ten, by location of where they lived in order to aid discussion on mobility and accessibility in their local area, and lasted around one and a half hours. Participants also took part in a telephone interview, lasting between 30 and 45 minutes, and completed a travel diary highlighting key information about their travel over a four week period. The focus groups took place six weeks apart and the diaries and interviews took place within the period between the groups. Because the study was iterative, the direction of discussion was dictated very much by the participants themselves and a very loosely structured topic guide was developed for each data collection method. The focus groups particularly addressed the extent to which travel and driving are socially constructed, the interviews focused on individual conceptualisations of travel and driving needs, and the diaries gave information about specific travel activities. Those who had given up driving were also invited to discuss the reasons for giving-up driving and how their needs were met without a car. The focus groups and interviews were recorded using digital Dictaphones and were transcribed verbatim.

\section{Trustworthiness of the research}

Checks of integrity, trustworthiness, validity and consistency were ensured during data collection and analysis. The use of different data collection techniques, coupled with extensive researcher notes enabled a triangulation of data which addressed similarities and explored differences amongst the data. Areas of contention were further discussed with participants during the iterative process. In addition, two researchers were involved in analysing the data so areas of consistency and contention could be examined. Areas of consistency were reported and areas of contention were discussed and debated amongst the researchers (and participants were appropriate) until a decision was made over the inclusion or exclusion of the data in the write-up.

Data Analysis

This is a final pre-print version of: Musselwhite, C. and Haddad, H. (2010). Mobility, accessibility and quality of later life. Quality in Ageing and Older Adults. 11(1), 25-37. ISSN: 1471-7794 (Print) 2042-8766 (Online) 
Data analysis began alongside the data collection to aid the iterative process. A transcript of the focus group or interview was coupled with reflexive notes made by the researcher and analysed by a process of Constant Comparative Analysis (Glaser, 2001; Goetz and LeCompte, 1981; Janesick, 1994; Lincoln and Gruba, 1985). In line with grounded theory open, axial and structured coding were used on the data. Open coding produced a summary of the data which was again reduced through detection of general, relevant and essential themes using axial coding. Relationships in the data were analysed with their associated causal properties and contextual conditions. Further data analysis occurred at the end of the data collection in light of new findings.

\section{Findings and Discussion}

The findings from the research prompt an immediate consideration and discussion and hence both findings and discussion are presented together in the paper. The findings begin by exploring a hierarchical model that was developed following discussion of why older people need to be mobile that takes into account that being mobile relates to needs beyond accessibility. Findings suggested that the car best met such needs and hence results explore what happens to these needs when driving is no longer an issue and how society is geared up towards supporting accessibility but not necessarily other forms of mobility.

\section{What is achieved by being mobile?}

The findings from the research allowed the researchers to create three distinct categories of needs older people have relating to travel, utilitarian (primary) needs, affective(secondary) needs and aesthetic (tertiary), which could be placed in a hierarchy (see figure 1). The level of participants' self-awareness or consciousness of these needs varied. They immediately discussed and hence were very conscious of utilitarian needs, but less aware of affective needs and even less aware of aesthetic needs.

This is a final pre-print version of: Musselwhite, C. and Haddad, H. (2010). Mobility, accessibility and quality of later life. Quality in Ageing and Older Adults. 11(1), 25-37. ISSN: 1471-7794 (Print) 2042-8766 (Online) 


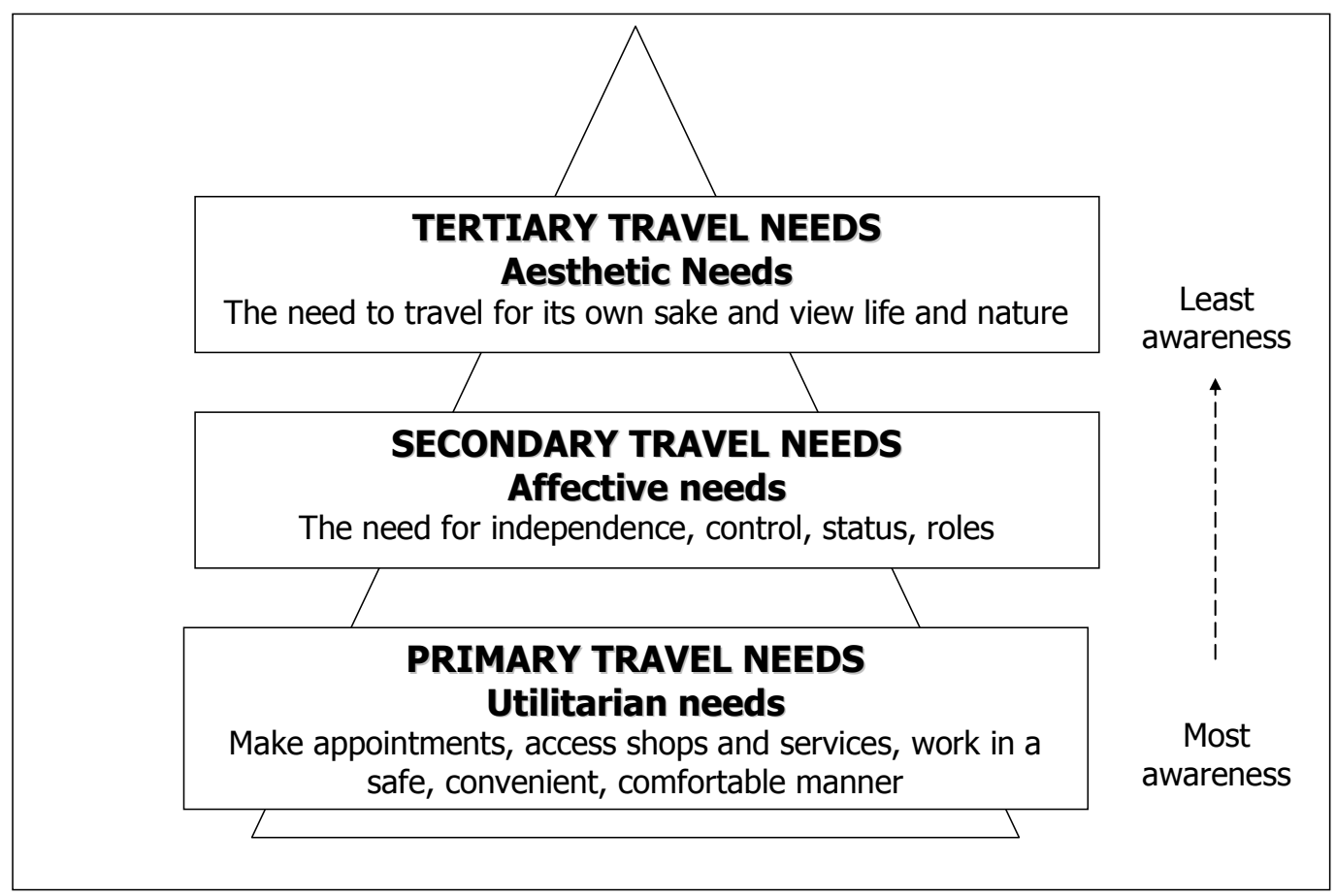

Figure 1 The three levels of mobility needs of older drivers by self-awareness of the need

\section{Utilitarian needs}

Analysis of the data produced an initial primary level of travel need, which highlighted that the dominant need for travel is related to a derived demand and a need for accessibility. This has been termed utilitarian needs as it shows travel serving a function of accessing other means. This level of need suggests older people are mobile in order to get from A to B in a cheap, efficient and safe manner to complete daily tasks, visiting shops, accessing services, fulfilling appointments, visiting friends, attending social events, going to work and helping others. This was often related to very basic needs of survival and was amplified and repeated throughout the data collection phases, as noted here by two participants in different stages of the research,

"Being mobile is vital to keep alive in this day and age isn't it. You got to get around for shopping and get to the doctors haven't you." (Male, driver, focus group, rural area)

"We live in a mobile society. Everything we need just to get by is all located apart from each other, supermarkets, friends, family, hospitals, schools" (Male, driver, interview)

This is a final pre-print version of: Musselwhite, C. and Haddad, H. (2010). Mobility, accessibility and quality of later life. Quality in Ageing and Older Adults. 11(1), 25-37. ISSN: 1471-7794 (Print) 2042-8766 (Online) 
How by being mobile these practical needs are fulfilled has been well documented (see Davey, 2007; DfT, 2001). Car driving was often cited as the easiest way of meeting these needs; for example in terms of carrying heavy shopping, minimising walking and several essential duties can be combined and executed in a short amount of time, as noted in several focus groups, for example,

"The car is vital to us oldies. How else could we carry shopping bags back home" (Male, driver, focus group, urban area)

"The car is cheap, efficient and you can carry your shopping and your friends and family around" (Female, driver, focus group, rural area)

Travel helps fulfil important social needs. The ability to drive and be mobile helps people maintain a rich and varied social life, making it possible to visit friends and family, and attend leisure and recreational events easily as one female noted in a semi-urban focus group which was met with much agreement,

Female: "Much of my time is spent travelling around to meet friends. They all live all over the place you see"

Male: "yes, yes same here" (Focus group, drivers, semi-urban area)

These were closely linked to participants' quality of life, especially with regard to emotional needs as one female participant noted,

"If I couldn't travel and get to see my friends, I don't know where l'd be. I'd be a sad, lonely, mess!" (Female, driver, interview)

The journey itself can be socially rewarding, for example, $67 \%$ of all journeys made by participants were made with at least one companion. Moreover, although the need for travel seems largely practical the social interaction that travel allows is arguably equally important. Thus, travel can be viewed as reducing social isolation and increasing social interaction. The importance of strong social networks has long been shown to be associated with quality of life for older people. It especially enables mutual practical, emotional and physical support which can reduce stress (Cobb, 1976) and even illness (Jung, 1984).

\section{Affective needs}

In addition, affective needs, such as control and independence, are also fulfilled through travel, especially when a car is available. The concept of having a car waiting to be used if necessary or in the case of an emergency was common place, for example, one male in a focus group stated how vital it was in case of needing to help others,

This is a final pre-print version of: Musselwhite, C. and Haddad, H. (2010). Mobility, accessibility and quality of later life. Quality in Ageing and Older Adults. 11(1), 25-37. ISSN: 1471-7794 (Print) 2042-8766 (Online) 
"I mean knowing you can go anywhere you want to go is like a comfort blanket even if you don't do much travelling about. I could visit friends in hospital or help a friend with a lift somewhere easily if I have a car to hand" (Male, driver, focus group, semi-urban area)

In addition, this was linked in many cases to quality of life in terms of comfort and security,

"I don't get out much in my car now. But I have one just in case, what if my wife breaks her leg or something or falls, Heaven forbid...but you never know. I know I got it if I need it see. That's very important to me...to feeling comfortable with day to day life." (male, driver, interview)

Independence that the car affords has been well documented (e.g. Burns, 1999; Kostyniuk, et al., 2000). Webster et al., (2002) cited the ability "to go where you want to" as one of main advantages of cars and driving for older people. Similarly, potential travel, which Metz (2000) describes as the knowledge that a trip could be made even if it is not actually undertaken, is also important. This perceived control is vitally important to quality of life in terms of health and happiness (for example see Langer and Rodin, 1976). Lack of control can lead to a poor quality of life linking to learned helplessness and depression (Seligman, 1975; Schulz and Hanusa, 1978).

Participants articulated the need to be part of society and how driving was linked to this. Driving is firmly embedded in society. It is 'normal' to drive a car and 'normal people' are expected to do this, and this was very well articulated by one male in a focus group who highlighted the importance of feeling part of society,

"It is the one thing that allows me to compete with youngsters. It is something I can probably still do as well as when I was a young man. I feel able to be part of society" (Male, driver, focus group, semi-urban area)

There are symbolic aspects to driving which allows drivers to be both accepted as normal and to manipulate impressions of themselves through their cars. To some extent driving can be seen as ageless. Eisenhandler (1990) suggests driving is a way of "warding off old age identity". This is particularly the case for men, where driving is linked both to personal and financial status (Webster et al., 2002) and displays that they are active, healthy and have done well for themselves in life, for example as one male said,

"Well you know you want to let people know at your stage of life that you've done well don't you. You should have a car like that and all that" (Male, driver, focus group, urban area)

Car ownership and driving is associated with masculinity, youthfulness, status and power (Siren and Hakamies-Blomqvist, 2005). Traditionally the love of driving and of owning a car has been associated with younger male drivers (see Davey, 2007; and Webster et al., 2002), but it is very much part of older people's lives as noted by the male participants, as one participant noted,

This is a final pre-print version of: Musselwhite, C. and Haddad, H. (2010). Mobility, accessibility and quality of later life. Quality in Ageing and Older Adults. 11(1), 25-37. ISSN: 1471-7794 (Print) 2042-8766 (Online) 
"Well, I still enjoy motoring, driving and the like. I love my car and I'm proud to own it" (male, driver, interview)

Female participants were more likely to view their driving in terms of their role, in particular as Mother, Grandmother, helper or carer to others and this was linked to improving quality of life by spending time with family, as one female stated with some passion in her interview,

"I pick up my Grand-daughter from school. I can't do that without my car. I love doing that for my daughter and love being with my Grand-daughter..I feel close to my family and get to spend quality time with them. That's thanks to the car! I appreciate that I really do" (female, driver, interview)

Hence, the findings suggest that the type of mobility afforded by a car goes beyond accessibility and links into issues of psychological wellbeing and quality of life associated with feeling part of society, identity, status and roles.

\section{Aesthetic needs}

The importance of enjoying the journey itself was a key motivation for travel. Specifically, driving affords the possibility for older people to view natural scenery such as forests, trees and the sea. The need for contact with nature, termed biophilia, has been well-documented (see Kellert and Wilson, 1993) and can create restorative responses and as such can reduce stress and anxiety and improve health (Ulrich, 1979). Travel by car allows these interactions to take place, even for those with reduced personal mobility and was discussed by several of the participants,

"Until I moved into my (retirement) flat, I loved looking at my garden, how it changes throughout the seasons. With my car, at least, I can still visit parks and the forest regularly to watch them change" (Female, driver, interview)

"We go down to the coast regularly to see the sea. I love being by the sea. We couldn't do it if we didn't have a car. It makes you feel alive" (Male, driver, interview)

"Sometimes I take the long way round to drive past the forest and see the trees, especially in Autumn." (Male, driver, interview)

Participants mentioned how driving also allows escapism and relaxation; important for good mental and physical health (Driver, et al., 1991; Weissinger and Iso-Ahola, 1984), and the need to explore, challenge oneself, create and discover, and hence continue learning, through using cognitive skills, as one male mentioned again this was linked to ageing and youthfulness,

"You know - driving keeps my mind active and young" (Male, driver, interview)

This is a final pre-print version of: Musselwhite, C. and Haddad, H. (2010). Mobility, accessibility and quality of later life. Quality in Ageing and Older Adults. 11(1), 25-37. ISSN: 1471-7794 (Print) 2042-8766 (Online) 
The sense of mastery and achievement is something older drivers tend to feel for safe completion of a journey (see Ellaway et al., 2003).

It can be argued here that travel (largely by car) is allowing a temporal mobility (a movement of mind) and accessibility to aesthetics, rather than to a practical good or service. Individuals link this mobility and accessibility very much to quality of life, especially noting that quality of life is enhanced by the very fact that the journey is not necessary. They often view quality of life as immersion in a world beyond everyday survival and completion of ordinary tasks to a higher level of quality, as described well by one male in an interview,

“That's what the car does you see. Takes you where you don't need to go, you see. And for me that's life. Not just day to day stuff, not just living to survive, but what else can be on offer, going beyond survival - seeing real life, a painting, a forest, the sea." (male, driver, interview)

\section{Giving-up driving and travel needs}

For those in the group who had given-up driving there was a great variation in age, with a mean of 74 years, which compares favourably to national averages for the UK which is 72 years of age (DfT, 2001). On the whole for this group of participants, accessibility is, perhaps surprisingly, not especially an issue; the decrease in personal mobility associated with giving-up driving has been supplemented by lifts and utilising public transport, resulting in a meeting of utilitarian needs in a safe, efficient, cheap manner. However, it is the mobility needs associated with affective and aesthetic needs that are largely unmet and this has a detrimental effect on older people's quality of life, as will be discussed below.

\section{Utilitarian needs}

Prior to giving-up driving there is great anxiety about not be able to go shopping or attending the doctor's surgery without huge planning and inconvenience. Having given-up driving, new approaches to getting around have to be devised. A variety of informal heuristics were developed by the participants, shown in Table 1, including issues such as whether there is a seat at the bus stop, whether buses are normally late or early and whether it is practical to carry shopping home. They also found friends and family willing to help them out. Overall, despite some changes and difficulty, this level of need was largely met following giving-up driving. Hence accessibility to key services was not especially compromised with a reduction in private mobility afforded by the car. Often social aspects of the drive were noted, for example one female described the help as a social event,

This is a final pre-print version of: Musselwhite, C. and Haddad, H. (2010). Mobility, accessibility and quality of later life. Quality in Ageing and Older Adults. 11(1), 25-37. ISSN: 1471-7794 (Print) 2042-8766 (Online) 
"Well Dorothy and David from number 3 take me shopping every week, we all go, we have a bit of a time of it you know, it's a kind of outing. I never expected that. I thought people like to, you know, keep themselves to themselves." (Female, gave-up driving at 80 , interview)

Table 1: Types and sources of information required when using buses following giving-up driving

\begin{tabular}{|c|c|c|}
\hline New Information sought on: & Secondary information: & $\begin{array}{l}\text { Primary information } \\
\text { source: }\end{array}$ \\
\hline Bus stop location & $\begin{array}{l}\text { Start and destination; route } \\
\text { knowledge }\end{array}$ & $\begin{array}{l}\text { Published timetable, } \\
\text { friends and family }\end{array}$ \\
\hline Timetable information & $\begin{array}{l}\text { Start and finish times, } \\
\text { different days of week etc. }\end{array}$ & Published timetable \\
\hline Time to/from bus stop & Start and destination & $\begin{array}{l}\text { Friends and family, } \\
\text { own experience }\end{array}$ \\
\hline Quality of walk & $\begin{array}{l}\text { Hills, safety, quality of } \\
\text { pavement }\end{array}$ & Own experience \\
\hline Quality of bus stop & Seats, shelter & Own experience \\
\hline Bus arrival norm & $\begin{array}{l}\text { Usually early or late, } \\
\text { predictability, reliability }\end{array}$ & Own experience \\
\hline Bus norms & $\begin{array}{l}\text { How to purchase a ticket, } \\
\text { business, best places to sit, } \\
\text { how to alight }\end{array}$ & Own experience \\
\hline Cost & $\begin{array}{l}\text { Learn cheapest routes, } \\
\text { times of the day, ticket } \\
\text { types etc. }\end{array}$ & $\begin{array}{l}\text { Friends and family, } \\
\text { own experience }\end{array}$ \\
\hline Carrying & $\begin{array}{l}\text { What you can/cannot carry; } \\
\text { how you can carry more if } \\
\text { needed }\end{array}$ & Own experience \\
\hline
\end{tabular}

\section{Affective needs}

It is certainly the case that giving-up driving has detrimental effects on social and psychological issues, however. Participants mentioned feelings of depression, anxiety and annoyance that in some cases were enduring, for example,

This is a final pre-print version of: Musselwhite, C. and Haddad, H. (2010). Mobility, accessibility and quality of later life. Quality in Ageing and Older Adults. 11(1), 25-37. ISSN: 1471-7794 (Print) 2042-8766 (Online) 
“It's hard to explain I suppose. You just don't seem like you belong. I suppose yes there are feelings that you might be ready for the scrapheap now. The first step to it, you know" (Male, gave-up driving at 76 , interview).

These were worse for those who had not planned to give-up driving and had been instructed to do so, or did so following an unforeseen negative incident. Not surprisingly, individuals who were negatively affected in such a manner, also reported having a reduced quality of life, for example,

"the lack of getting out and about is truly depressing. It makes you feel trapped...you can't get out and about to see anything, and yes, it has reduced my general enjoyment of life" (Male, gave-up driving at 82 , interview)

Individuals who took giving-up driving better had largely planned to give-up driving or at least taken the decision themselves, often after a long period of reducing driving through giving-up driving at busy times, at night or on motorways, for example. Such individuals were more likely to be female and described giving-up driving as not interfering with who they were as individuals and hence distanced themselves and their identity to mobility afforded by the car, for example, "To be honest I'm not sure it's mattered as much as I expected it to. I haven't changed as a person. I'm still me. I thought it'd be awful." (Female, gave-up driving at 79, interview) Hence, the need for travel can again be shown to go beyond simply being linked to accessibility when describing its importance in terms of quality of life. The car is particularly important in fulfilling such needs, but planning to give-up the car and being in control of such a process is linked with less negative affect. However, it could be argued that such individuals were not linked so deeply in an affective manner with their car prior to giving-up driving and hence were able to take the initiative to get rid of the car. Those more emotionally attached to their car and driving would naturally find it more difficult to give up driving and suffer the consequences when givingup driving. However, it shows the importance for policy and practice to consider the importance of addressing affective issues when supporting or encouraging individuals to give-up their car.

Aesthetic Needs

This level of needs was hardly met at all for those who had given-up driving, except where family or friends who took them to see countryside or the sea, but there was a reluctance to ask others to simply "go out for a drive", as one person explained in relation to a discussion on travelling for its own sake,

"You can't ask other people to take you out for "a drive". They'd think you'd lost their senses. Anyway they have got better things to be doing with their time, then ferrying me about just for the sake, like" (Female, gave-up driving aged at 80 , interview)

This is a final pre-print version of: Musselwhite, C. and Haddad, H. (2010). Mobility, accessibility and quality of later life. Quality in Ageing and Older Adults. 11(1), 25-37. ISSN: 1471-7794 (Print) 2042-8766 (Online) 
In addition, it was common for participants to note that public transport was seen as not appropriate for visiting beauty spots, for example, one female in an interview noted,

“The bus doesn't really go where you would want. The route isn't pretty. It just does the houses and the shops. The views are ordinary" (Female, gave-up driving at 80 )

It was certainly articulated that a reduction in this type of travel negatively affected quality of life, "I certainly miss it. It was something I took for granted but now its gone I miss it and it has left a bit of as gap in my enjoyment of life, certainly." (Female, gave-up driving at 78)

Overall, this seems to be another level of need that requires some extra consideration in policy and practice aimed at improving quality of life.

\section{Meeting mobility needs through walking}

Walking is an important behaviour for older people, especially as they give-up driving. The research investigated the role of walking with regards to the travel needs of older individuals. The research suggests, travel and being mobile in general are more than just a means of achieving accessibility. This was re-emphasised in discussions on being a pedestrian. The importance of outdoor spaces for meeting people and socialising, enjoyment, escape from indoors or from routine places and for enhancing good feelings or positive experience was also noted by the participants, which could be said to enhance quality of life as one female noted,

"being out and walking somewhere nice is very important to me as an individual, it's part of my life" (Female, driver focus group, rural area)

The chance encounter was also noted as being important, and was articulated both in terms of chance encounters with people and was frequently noted in similar responses to these examples, “First time I went walking I didn't get very far! I bumped into so many people I knew!" (Male, driver, focus group, urban area)

"If the weathers nice you can end up meeting all sorts of people out and about" (male, driver, interview)

Chance encounters may also be with places, that individuals di not know existed,

"you can go for a walk and if you're not too worried about getting lost you discover places you didn't know existed" (male, given-up driving at 80, interview)

"Walking like slows things down. You see more things you don't normally see!" (female, given-up driving at 72 , interview)

This is a final pre-print version of: Musselwhite, C. and Haddad, H. (2010). Mobility, accessibility and quality of later life. Quality in Ageing and Older Adults. 11(1), 25-37. ISSN: 1471-7794 (Print) 2042-8766 (Online) 
Participants suggested a number of barriers to walking in the public realm, including poorly kept pavements, lack of public conveniences and lack of benches, echoing other research (see also I'DGO, 2007). Streets where traffic dominates through speed and volume were off-putting, especially where crossing the street was made difficult because of wide junctions with poor lines of sight and illegal parking, agreeing with previous research (see also Marsden et al., 2006). These elements are real barriers to walking, for example an older male noted the sheer width of the road coupled with high amount of traffic stops him going out,

"It's so wide, there's no crossing, so you have to take your life in your hands. A dangerous thing to do at my age" (male, given-up driving at 80 , interview)

In addition, personal safety issues were also a concern amongst participants and previous research highlights such issues need to be addressed (see also Waters et al., 2007).

Individuals noted that anxiety over walking did reduce their quality of life, for example one individual stated a combination of internal and external factors negatively impeded on pedestrian activity and hence quality of life,

"I wish I didn't feel like this about walking. But it's certainly an issue in my life, not really feeling like I can get out and about. You do learn to accept it but it does affect my life" (female, given-up driving at 72 , interview)

Important as the car might be in meeting travel needs, walking amongst the older population should be encouraged. Participants saw the benefits of walking and felt they were linked to quality of life, if barriers (largely physical infrastructure barriers) could be reduced. Current knowledge emphasises the importance, for example, physical inactivity is a major cause of disease (WHO, 2003) and quality outdoor spaces contribute to a more active life-style and positively benefit older people's health and life satisfaction (Sugiyama and Ward Thompson, 2007a,b,c).

\section{Conclusion}

Overall, this findings and discussion highlight that mobility is not only important in fulfilling the essential utilitarian needs of older people, but also in enhancing social networks and social interaction, creating a sense of control and independence, denoting status and role and helping people interact with nature and exercise cognitive skills. Hence, mobility, although linked to accessibility, is more than that to the older individuals in this research, especially when relating travel to quality of life. Quality of life is described by participants themselves as meeting basic needs but also in going beyond that to support social and emotional needs. Quality of life is additionally linked to performing activities that are seen as non-essential but are pleasurable, for

This is a final pre-print version of: Musselwhite, C. and Haddad, H. (2010). Mobility, accessibility and quality of later life. Quality in Ageing and Older Adults. 11(1), 25-37. ISSN: 1471-7794 (Print) 2042-8766 (Online) 
example is linked to affective and aesthetic motives for travel and mobility rather than just accessibility alone. Individuals saw their quality of life being emphasised by mobility relating to accessibility. Older people have to be able to access services, visit shops and hospitals to have a basic quality of life. However, many older people spoke about how quality of life for them was going beyond accessing the daily needs and encompassed peripheral aspects such as viewing scenery, discovering new places and having chance encounters.

Driving a car helps fulfil utilitarian needs to a maximum and without a car, affective and aesthetic needs would not be met. As people give-up driving they rely on either public transport or other people for help with their travel. This reduces the fulfilment of many affective and aesthetic needs, and participants discussed how this reduced their own perceptions of quality of life. Hence, it can be seen that a lack of mobility, perhaps even if accessibility is fine, can contribute to depression (e.g. Fonda, et al., 2001; Ling and Mannion, 1995) and isolation (Johnson, 2002). Nevertheless, there is scope for walking in particular to fulfil such needs. However, to encourage older people to walk more, streets need to be re-designed away from simple movement corridors to spaces where people would like to stay and become immersed. Interventions aimed at meeting mobility needs often concentrate on the most commonly articulated utilitarian needs, an implication is that affective and aesthetic needs may go unmet, particularly when private travel modes have to be foregone.

This study deliberately used a small in-depth methodology in order to scope needs arising from the participants themselves and hence cannot be said to represent the viewpoints of the majority of older people. Nevertheless, the findings amplify and build on knowledge developed in previous results as articulated throughout the paper. Future studies need to build on the separation of mobility and accessibility in order to understand quality of life for all people, especially those who do not necessarily have use of the car which seems to be important to achieve maximum mobility and accessibility in a hypermobile society. Finally, it is recommended that policy and practice must go beyond simply supporting access issues with regards to travel for older people, especially when they give-up driving, and address the affective and aesthetic issues of travel behaviour, that according to these findings are so closely related to quality of life.

\section{References}

Adams, J. (1999). The social implications of hypermobility. Proceedings of the Ottawa Workshop on Environmentally Sustainable Transport: The Economic and Social Implications of Sustainable Transportation.

Burd H. J., Judge S. J. and Flavell M. J. (1999) Mechanics of accommodation of the human eye. Vision Research 39 (9), 1591-5

This is a final pre-print version of: Musselwhite, C. and Haddad, H. (2010). Mobility, accessibility and quality of later life. Quality in Ageing and Older Adults. 11(1), 25-37. ISSN: 1471-7794 (Print) 2042-8766 (Online) 
Burns, P.C. (1999), Navigation and the Mobility of Older Drivers, The Journal of Gerontology, 54B (1), 49-55.

Charlton, J. L., Oxley, J., Fildes, B., \& Les, M. (2001). Self-regulatory behaviour of older drivers. Paper presented at the Road Safety Research, Policing and Education Conference, Melbourne, Victoria, Australia.

Clarke, D. (2009). Older drivers' traffic collisions: 'In youth we run into difficulties; in old age difficulties run into us' Proceedings of the $19^{\text {th }}$ Behavioural Studies Seminar, Horsley Park, East Horsley, Leatherhead 30 March - 1 April

Cobb, S. (1976). Social support as a moderator of life stress. Cultural Psychology, 17, 83-98.

Cushman, L. A. (1996). Cognitive capacity and concurrent driving performance in older drivers. IATSS Research, 20(1), 38-45

Davey, J. A. (2007). Older people and transport: coping without a car. Ageing and Society, 27, 49-65.

Der, G., and Deary I. J. (2006) Age and sex differences in reaction time in adulthood: Results from the United Kingdom Health and Lifestyle Survey. Psychology and Aging, 21, 62-73

DfT (Department for Transport) (2001). Older Drivers: a literature review. London: Department for Transport. Available at:

http://www.dft.gov.uk/pgr/roadsafety/research/rsrr/theme3/olderdriversaliteraturerevie4770 (last accessed 5th March 2008).

DfT (Department for Transport) (2006) National Travel Survey Great Britain 2005. London:

Department for Transport. Available at http://www.dft.gov.uk/pgr/statistics/datatablespublications/personal/mainresults/nts20051/ (last accessed $5^{\text {th }}$ March 2008).

Driver, B. L., Tinsley, H. E. A., and Manfredo, M. J. (1991). The paragraphs about leisure and recreation experience preference scales: Results from two inventories designed to assess the breadth of the perceived psychological benefits of leisure. In B. L. Driver, P. J. Brown, \& G. L. Peterson (eds.), Benefits of Leisure. State College, PA: Venture Publishing, Inc, 263286

Eisenhandler, S. (1990). The asphalt identikit : old age and the driver's license. International Journal of Aging and Human Development, 30(1), 1-14.

Ellaway, A., Macintyre, S., Hiscock, R. and Kearns, A. (2003). In the driving seat: psychosocial benefits from private motor vehicle transport compared to public transport. Transportation Research Part F. 6, 217-231.

This is a final pre-print version of: Musselwhite, C. and Haddad, H. (2010). Mobility, accessibility and quality of later life. Quality in Ageing and Older Adults. 11(1), 25-37. ISSN: 1471-7794 (Print) 2042-8766 (Online) 
Elliott, D., Elliott, B. and Laysight, A. (1996). Older Drivers Risk and Countermeasures Source Book. Elliott and Shahanan Research report for Federal Office for Road Safety, Australia

Engwicht, D. (1999). Street reclaiming : creating livable streets and vibrant communities. Pluto books.

Fonda, S. J., Wallace, R. B., \& Herzog, A. R. (2001). Changes in driving patterns and worsening depressive symptoms among older adults. Journal of Gerontology: Social Sciences, 56B(6), S343-S351

Glaser, B. G. (2001). The Grounded Theory Perspective: Conceptualization Contrasted with Description. Mill Valley, Ca.: Sociology Press.

Goetz, J. P., \& LeCompte, M. D. (1981). Ethnographic research and the problem of data reduction. Anthropology and Education Quarterly, 12, 51-70

Hamilton-Baillie, B. and Jones, P., (2005). Improving traffic behaviour and safety through urban design. Civil Engineering 158 (May), 39-47.

Hart, J. (2008). Driven to excess. A study of three streets in Bristol. MSc Thesis.

Hewson, P. (2006) Ageing drivers or ageing casualties? Presented at the Older People in Rural Area (OPeRA) Research Conference, Taunton, July 4th 2006. Available at http://www.plymouth.ac.uk/files/extranet/docs/HSW/HewsonTaunton0407206.pdf (last accessed 9th March 2007)

Hultsch, D. F., MacDonald, S. W. S., \& Dixon, R. A. (2002). Variability in reaction time performance of younger and older adults. Journal of Gerontology: Psychological Sciences, 57B, 101-115

I'DGO (2007) Older People and the Outdoors. Inclusive Design for Getting Outdoors. Available at http://www.idgo.ac.uk/older people outdoors/index.htm (last accessed 5th March 2008).

Janesick, V. J. (1994). The dance of qualitative research design: Metaphor, methodology, and meaning. In N. K. Denzin, \& Y. S. Lincoln (Eds.), Handbook of qualitative research (pp. 209-219. Thousand Oaks, CA: Sage.

Jevas, S. \& Yan, J.H. (2001). The effect of aging on cognitive function: A preliminary quantitative analysis. Research Quarterly for Exercise and Sport: Abstracts of Completed Research, 72(1), A-49.

Johnson, J. E. (2002). Why Rural Elders Drive Against Advice. Journal of Community Health Nursing, 2002, 19(4), 237-244.

Jung, J. (1984).Social Support and Its Relation to Health: a Critical Evaluation. Basic and Applied Social Psychology 5, 143-165.

This is a final pre-print version of: Musselwhite, C. and Haddad, H. (2010). Mobility, accessibility and quality of later life. Quality in Ageing and Older Adults. 11(1), 25-37. ISSN: 1471-7794 (Print) 2042-8766 (Online) 
Kellert, R., and Wilson, E.O. (eds) 1993. The biophilia hypothesis. Island Press, Washington DC.

Kostyniuk, L. P., Shope, J. T., \& Molnar, L. J. (2000). Driving reduction/cessation among older drivers: Towards a behavioural framework. In 9th International Association for Travel Behaviour Conference, Gold Coast, Queensland, Australia, July 2-7, 2000.

Langer, E.J. and Rodin, J. (1976). The effects of choice and enhanced responsibility for the aged: A field experiment in an institutional setting. Journal of Personality and Social Behaviour, 34, 191-198.

Lincoln, Y. S., \& Guba, E. G. (1985). Naturalistic inquiry. Newbury Park, CA: Sage

Ling, D. J. and Mannion, R. (1995), Enhanced Mobility and Quality of Life of Older People: Assessment of Economic and Social Benefits of Dial-a- Ride Services, in Proceedings of the Seventh International Conference on Transport and Mobility for Older and Disabled People, Vol. 1, DETR, United Kingdom.

Marottoli, R. A., \& Richardson, E. D. (1998). Confidence in, and self rating of, driving ability among older drivers. Accident Analysis and Prevention, 30(3), 331-33.

Marsden, G., Jopson, S. Cattan, M and Woodward, J. (2006).Planning Transport to Support the Independence of Older People. Mind the Gap. Presentation at Transport for Older People: More User Focused Workshop, University of Leeds, October. Available at http://www.sparc.ac.uk/workshops/10 2606 transport/pdf/Annn etal.pdf (Last accessed 5th March 2008).

Maslow, A. H. (1970). Motivation and Personality, 2nd. ed., New York, Harper \& Row.

McKnight, A.J. and Adams, B.B. (1970). Driver education task analysis. Volume 1: Task descriptions.Alexandria, VA: Human Resources Research Organization, Final Report, Contract No FH 11-7336.

Metz, D. (2000). Mobility of older people and their quality of life. Transport Policy, 7, 149-52.

Musselwhite, C. B. A. and Haddad, H. (2007). Prolonging the Safe Driving of Older People through Technology. SPARC Project Final report, October 2007. Centre for Transport \& Society, University of the West of England, Bristol.

O'Connell, M. (2002). Social psychological principles: 'The group inside the person' . In R. Fuller \& J.A. Santos (2002) Human Factors for Highway Engineers, Amsterdam: Pergamon, 201215

ONS (Office for National Statistics) (2004). Focus on Older People. London: Office for National Statistics.

This is a final pre-print version of: Musselwhite, C. and Haddad, H. (2010). Mobility, accessibility and quality of later life. Quality in Ageing and Older Adults. 11(1), 25-37. ISSN: 1471-7794 (Print) 2042-8766 (Online) 
Oxley, P.R. (1991) Elderly and disabled car users: A growing market in private transport for the elderly. TRL CR308., Crowthorne, Berkshire.

Paniati J. F. (1988), Legibility and Comprehension of Traffic Sign Symbols Proceedings of the Human Factors Society 32nd Annual Meeting, 1, 568-572.

Siren, A. and Hakamies-Blomqvist, L. (2005). Sense and sensibility : a narrative study of older women's car driving. Transportation Research, Part F: Traffic Psychology and Behaviour, 8, 213-28

Strauss, A., \& Corbin, J. (1998). Basics of Qualitative Research: Grounded Theory Procedures and Techniques. Newbury Park, CA: Sage Publications.

Sugiyama, T. and Ward Thompson, C. (2007a). Outdoor environments, activity and the well-being of older people: conceptualising environmental support. Environment and Planning A, 39, 1943-1960.

Sugiyama, T., and Ward Thompson, C. (2007b). Measuring the quality of the outdoor environment relevant to older people's lives. In: Ward Thompson, C. and Travlou, P., (eds.) Open Space: People Space. Abingdon, UK: Taylor and Francis, pp 153-162.

Sugiyama, T., and Ward Thompson, C. (2007c). Older people's health, outdoor activity and supportiveness of neighbourhood environments. Landscape and Urban Planning, 83, 168175

Tomassini, C. (2004). Demographic Data for an Ageing Population. In ONS (2004). Population Trends. Winter 2004, London: Office for National Statistics, 23-30.

Ulrich, R. S. (1979). Visual landscapes and psychological well-being. Landscape Research, 4, 17-23.

Waters, J., Neale, R. and Mears, K. (2007). Design and community regeneration: investigating personal safety concerns of older people in socio-economically deprived communities in South Wales. SPARC Project Final Report. University of Glamorgan, Wales.

Webster, N., Gow, J., Gilhooly, M., Hamilton, K., O’Neill, M. and Edgerton, E. (2002) Transport barriers to activity in old age. Active Ageing: Myth or Reality? (In Proceedings of the British Society of Gerontology $31^{\text {st }}$ Annual Conference, $12^{\text {th }}-14^{\text {th }}$ September 2002, University of Birmingham) pp117-121, ISBN: 0704423669.

Weissinger, E., and Iso-Ahola, S. E. (1984). Intrinsic leisure motivation, personality and physical health. Society and Leisure, 7(1), 217-228.

Welford, A. T. 1977. Motor performance. In J. E. Birren and K. W. Schaie (Eds.), Handbook of the Psychology of Aging. New York: Van Nostrand Reinhold, , 450-496.

WHO (World Health Organisation) (2003) Health and development through physical activity and sport. Geneva, Switzerland: World Health Organization

This is a final pre-print version of: Musselwhite, C. and Haddad, H. (2010). Mobility, accessibility and quality of later life. Quality in Ageing and Older Adults. 11(1), 25-37. ISSN: 1471-7794 (Print) 2042-8766 (Online) 